\title{
A METHOD FOR THE STUDY OF SOIL FERTILITY PROBLEMS.
}

\author{
Bx JACOB G. LIPMAN,
}

Associate Professor of Agriculture, New Jersey Agricultural College

Experiment Station, New Brunswick, New Jersey, O.S.A.

Several years ago the writer's attention was called to the apparently favourable influence of field peas on oats when the two were grown together. The rank growth of the oats, their dark-green colour and the delayed ripening gave every indication of an abundant supply of available nitrogen compounds. On the other hand, oats seeded without the peas, at about the same time, were less rank in their growth and matured at an earlier date. Further observation and inquiry strengthened the impression in the writer's mind that the associative growth of legumes and non-legumes is frequently advantageous to the latter in that they are supplied with nitrogen compounds derived either from the decay of the fibrous roots of the legumes, or from the soluble materials passing out of the roots into the surrounding soil.

Because of the extreme scientific and practical interest attached to this question, it was decided to submit it to a careful study. This seemed the more desirable in view of the very frequent growing of mixtures of legumes and non-legumes not only in dairy sections, but also in those where the raising of cattle, swine and sheep, and the growing of general farm crops are prevalent. In North America winter vetch is grown together with rye and wheat, and in more favoured locations with barley and oats. Similarly, crimson clover is occasionally grown together with barley or oats for forage purposes. Cow peas and soy beans are commonly grown together with corn, sorghum, Kafir corn or millet, and are either harvested as green forage, or are ensilaged or "hogged off." Timothy and other grasses are frequently mixed with 
alsike, red or mammoth clover; while in natural pastures the clovers and other legumes are more or less prominent. In our Southern States corn and lima beans are grown together in order to provide the latter with proper support. Other mixtures of legumes and non-legumes have also been grown in America and Europe.

When considered from the nitrogen standpoint these combinations of legumes and non-legumes reveal possibilities of great economic importance. Should it be demonstrated that non-legumes could be provided with an abundant supply of nitrogen even in poor soils, by being grown together with legumes under proper conditions, it would become practicable not only to dispense with all or a portion of the nitrogenous manures employed for certain crops, but also to secure nonlegumes with an increased proportion of protein in the dry matter. In accordance with this thought a method was devised for the study of the reciprocal effects of legumes and non-legumes.

The method itself is very simple, as is shown in the figure. The outer vessel is an ordinary five-gallon glazed earthenware pot. The inner and smaller pots are made out of a very porous flint mixture, and differ only in that the pot on the left is glazed, while the pot on the right is unglazed.

In arranging the experiment for the study of the relations of legumes and non-legumes, the small and large pots were filled with white quartz sand, the smaller pots being placed inside the larger.

There were secured in this manner two portions of soil identical in composition and supplied with the same fertilizer materials. The two portions of soil were separated from one another by a porous wall in the one instance, and by a non-porous wall in the other. The legumes were planted in the large pot, that is, in the outer portion, while the non-legumes were planted in the small inner pot. Previous to planting the sand used as soil was supplied with all the essential mineral constituents and with a small amount of soil infusion in order to supply the bacteria for the inoculation of the legumes.

It was reasoned that if the legumes allow soluble nitrogen compounds to pass out of the tubercles and the roots, these soluble compounds will diffuse through the porous wall of the unglazed pot and supply nitrogen to the non-leguminous vegetation in the inner pot. On the other hand such diffusion cannot take place through the walls of the glazed pot and the non-legumes growing in it will starve for lack of nitrogen if none is supplied in the fertilizer material.

Accordingly field peas and oats were planted in the outer and inner 
pots respectively. Pure quartz sand was used as soil, and was supplied with all the essential mineral constituents. No nitrogen was applied, and the plants had no other source of supply except the atmosphere, or the slight amounts of nitrogen present in the seed or in the water used. The outer pot contained about $80 \mathrm{lbs}$. of sand, the inner pot about $20 \mathrm{lbs}$. The moisture conditions were kept uniform.

The figure sbows the glazed inner pot and corresponding large pot on the right and the unglazed inner pot and corresponding large pot on the left. It will be noted that the oats in the unglazed pot were

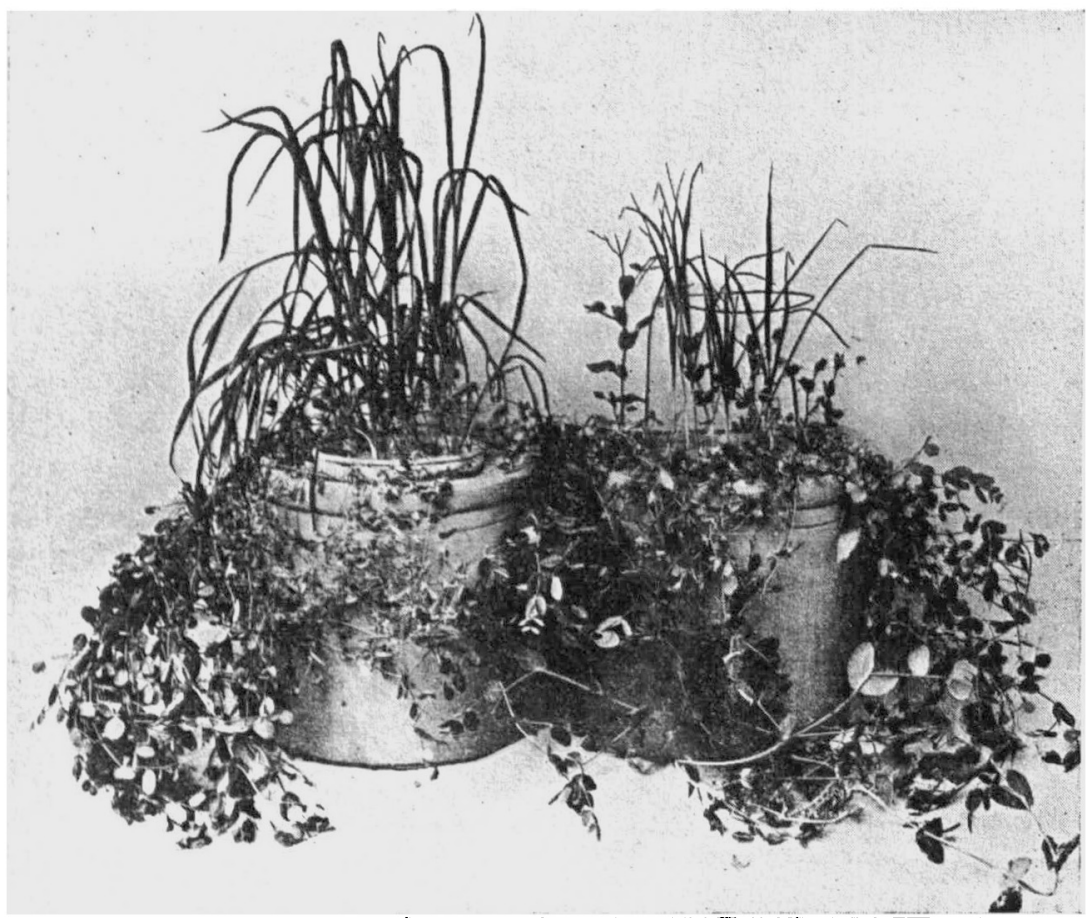

Onts in inner pots, peas in outer. Porous inner pot on left, glazed inner pot on right.

sturdier and were making better growth. The photograph does not bring out the much deeper colour of the oats growing in the unglazed pot. There was no doubt, however, that at the time this photograph was taken, that is, when the plants were about 10 weeks old, the oats in the unglazed pot were securing nitrogen from some source that was not available to the oats in the corresponding glazed pot. Every indication was thus supplied that soluble nitrogen compounds were diffusing through the unglazed porous wall and were being utilized by the oats. 
We have here a striking proof of the ability of oats to secure an adequate supply of nitrogen when growing together with field peas in a soil devoid of nitrogen. We have proof, further, that the nitrogen compounds supplied to the oats were soluble, and diffusible through porous earthenware. Subsequent weighing and analysis of the oats grown in glazed and unglazed pots, respectively, showed not only a much larger yield of dry matter and of nitrogen in the latter, but of dry matter containing nearly double the proportion of nitrogen as compared with that grown in the glazed pots. Since this is only a preliminary paper the analyses and other data are not given. Moreover, the purpose of this publication is not to discuss our results on the associative growth of legumes and non-legumes (we reserve these for publication at a future date), but to point out the wide usefulness of the method employed for the investigation of a great variety of soil problems.

The method may be employed, as we have employed it, for the study of the influence of various crops on the bacterial flora of soils. For this purpose the crops may be grown in the outer pots and the soil in the inner pots, glazed and unglazed, may be left uncropped. The samples drawn from the inner pots may be examined bacteriologically, and the differences found in the glazed and unglazed pots may be ascribed to the influence of the crop. Similarly the method may be employed for the study of the effect of various fertilizers on certain groups of soil bacteria; for the study of the influence of different crops on one another when grown continuously and in rotation; and for the study of the so-called toxic effect of plant-root excretions.

In order to secure satisfactory results with this method it is necessary to have special porous mixtures for the preparation of the inner pots. We have been able to secure satisfactory porous pots by mixing the clay with 25 per cent. of hard coal and 25 per cent. of soft coal. The pots made out of this mixture are fired in the usual way. As checks to take the place of the glazed pots described above we employ the same pots coated with asphaltum paint. These are impervious to diffusible salts as shown by our tests in the laboratory. It is hoped that the method outlined here will be tested by other investigators in the study of important soil problems. 